\title{
An Appraisal of Adaptation Measures to Climate Variability by Smallholder Irish Potato Farmers in South Western Uganda
}

\author{
Frank Mugagga* ${ }^{*}$, Alex Nimusiima, Julius Elepu \\ Department of Geography, Geo-Informatics and Climatic Sciences, Makerere University, Kampala, Uganda \\ Email: ^fmugagga@gmail.com
}

How to cite this paper: Mugagga, F., Nimusiima, A., \& Elepu, J. (2020). An Appraisal of Adaptation Measures to Climate Variability by Smallholder Irish Potato Farmers in South Western Uganda. American Journal of Climate Change, 9, 228-242. https://doi.org/10.4236/ajcc.2020.93015

Received: February 21, 2020

Accepted: September 5, 2020

Published: September 8, 2020

Copyright $\odot 2020$ by author(s) and Scientific Research Publishing Inc. This work is licensed under the Creative Commons Attribution International License (CC BY 4.0).

http://creativecommons.org/licenses/by/4.0/

\begin{abstract}
Climate change and variability are a reality and have had marked effects on both human and ecological systems. Adaptation to such effects either directly or indirectly is viewed as a novel way of reducing the spread of the associated risks. The study was conducted in Rubanda District with a general aim of evaluating the effectiveness of adaptation measures to climate variability used by smallholder Irish potatoes farmers. Specifically, we sought to appraise smallholder Irish potato farmers' perceptions about the effectiveness of climate variability adaptation measures and implications on Irish potato productivity. We undertook a cross-sectional study to collect data from total of 197 farmers using a structured questionnaire. Other participatory methods such as focus group discussions and key informant interview were also used to complement the household survey. Data were analyzed using SPSS Version 23 to generate descriptive statistics as well as relationships between the adaptation measures and the productivity of the Irish potatoes using a Cobb-Douglas production function. The Cobb-Douglas model revealed that the use of fertilizers was significantly and positively associated with productivity of Irish potato $(P<$ 0.001). Furthermore, Smallholder Irish potato farmers perceived the use of technology, terracing, early planting and application of fertilizers as the most effective climate variability adaptation measures. The study recommends that measures that are cost-effective, efficient and coherent should be promoted to offset the impacts of climate variability which would include the adoption of improved potato varieties and use of fertilizers with proper management of erosion. Off-season planting of Irish potatoes in the wetlands should be discouraged by the local administration and the National Environment Management Authority. This calls for a collective action involving the agricultural practitioners and inline civil society organizations to ensure that farmers have access to such inputs.
\end{abstract}




\section{Keywords}

Adaptation Measures, Climate Variability, Efficacy, Irish Potato Farmers, South Western Uganda

\section{Introduction}

Uganda's climate is naturally variable and is susceptible to impacts of climate variability such as floods, landslides and drought among others (Hepworth \& Goulden, 2008; NAPA, 2007; Mugagga et al., 2019). These events are already having negative socio-economic impacts such as water scarcity, proliferation of pests and diseases, and reduction in crop yields (Ampaire et al., 2017; CDKN, 2015).

Kikoyo \& Nobert (2015) revealed that average annual temperatures have been increasing at a rate of around 0.3 degrees per decade in most parts of Uganda since 1970 while rainfall does not show any significant trend in the same period but is highly variable from year to year. For example, Hepworth (2010) observed that rainfall in Uganda is expected to increase by $14 \%$ or fall by $7 \%$ below the 1970-1999 average by 2030. The implications of these changes in rainfall and temperature will be significant for food security and rain-fed agriculture which is the main source of livelihood among the rural farm households (Hepworth \& Goulden, 2008; Kikoyo \& Nobert, 2015). Studies show that there is a strong relationship between climate variability and quality of Irish potato farming in many regions in Africa (Hijmans, 2003; Karanja et al., 2014). For example, high temperatures cause a decrease in tuberisation and heavy rains damage potatoes. Byishimo (2017) observed that an increase in maximum temperatures by $1^{\circ} \mathrm{C}$ may lead to a decrease of potato yields by $31.8 \%$ in Rwanda. These changes will cause a decline in Irish potato yields and yet the crop is an important food and cash crop in Uganda and one of the dominant crops in South-Western Uganda, with over $80 \%$ of smallholder farmers in Rubanda District involved in it (MAAIF, 2010; Mbowa \& Mwesigye, 2016; Mugagga et al., 2019; UBOS, 2016). A study by Byamukama et al. (2018) revealed that climate variability related disasters like droughts and floods are key factors affecting potato growing in Rubanda District. Adapting to these changes is therefore key given that the calculated decrease in potato yields is large for many regions without adaptation by 2040 to 2060 (Hijmans, 2003). Farmers have adopted measures to counter the climate variability risks (Hisali et al., 2011; Kikoyo \& Nobert, 2015; Mugagga et al., 2019; Twagiramaria \& Tolo, 2016), however the effectiveness of such adaptation measures and their impact on crop production is not yet well understood in Rubanda District. A few studies (Kikoyo \& Nobert, 2015; Zizinga et al., 2015) conducted in Uganda to measure the performance of adaptation strategies further highlight the need for research into effectiveness of adaptation measures employed by farmers. Kikoyo \& Nobert (2015) revealed that adaptation measures applied by 
farmers in Uganda are questionable in terms of their effectiveness. This limited knowledge is also spelled out in the Uganda Climate Action Report (2015). This exemplifies a plausible gap in scholarship to which this study sought to address.

According to Brooks et al. (2011), success of adaptation measures can be measured in terms of efficacy, efficiency, acceptability, equity and implementability. Effectiveness has been observed as major criteria for evaluating the success of adaptation measures (Regmi, 2018). Effectiveness is the capacity of a system to adapt to achieve its objectives and it involves a reduction of impacts, exposure, risks and the avoidance of danger (Adger et al., 2005; Regmi et al., 2018). The study set out to appraise effectiveness because it relates to how successful an intervention is in delivering intended results. In order to achieve this, we sought to appraise smallholder Irish potato farmers' perceptions about the effectiveness of climate variability adaptation measures and implication on Irish potato productivity in Rubanda District

\section{Conceptual Framework}

The study hinges on the economic theory of production. The production function (PF) describes the relationship of transformation of inputs into outputs given the available level of technology that the farmer has (Gorgess \& Naby, 2012). Under given technological conditions, farm output is viewed as a function of farm size, labour, capital and other variables such as for example weather, agronomic practices and farm management practices. To put in the context of climate variability, the output production is viewed as a function of the traditional factors of production (land, labour and capital) and the different response mechanisms that a farmer applies to counter climate variability. These could involve application of fertilizers, use of improved seed varieties, timely planting and water harvesting.

Given its importance, several studies (Adams, 2005; Dharmasiri, 2009; Gorgess \& Naby, 2012; Kotulič \& Pavelková, 2014; Prasad \& Wagle, 2016) have applied the production function to unravel the interrelations between inputs and outputs of production; More so because of its ability to describe the rate at which resources are transformed into products (Kotulič \& Pavelková, 2014).

The most common of the production functions used to analyse the effectiveness of smallholder agricultural production is the Cobb-Douglas Production Function because of its superiority over the other functions. It is linear in logarithm transformation, empirically simple, computerization feasibility and adequate fit to data (Asefa, 2011; Bhanumurthy, 2002). More so, the elasticity of production and marginal productivity helps to establish the productivity of input factors (Dharmasiri, 2009). This model was also used because of its ability to model productivity (Prasad \& Wagle, 2016).

The theory behind the study hinged on the household's ability to make a production decision on the available adaptation measures such as mulching, irriga- 
tion, fertilizers, improved crop varieties, borrowing and timely planting to potato production.

However, along the decision making process are economic, environmental and social factors that affect the effectiveness of the adaptation process. Effectiveness of adaptation in terms of increasing the productivity of Irish potatoes would be achieved if the smallholder farmers wisely applied the adaptation measures. This would in turn lead to sustainable incomes to a farm household through the sale of the surplus output. It would also provide farmers with financial capital that would be used to spread the risk of climate variability by investing in other enterprises which would in turn reduce vulnerability to climate variability.

\section{Materials and Methods}

\section{Study Area}

This study was conducted in Rubanda District which lies in the South West of the Republic of Uganda. Rubanda District is bordered by Kabale District to the east, Rukungiri District to the north, Kanungu District to the north-west, Kisoro District to the west, and Rwanda to the south (Figure 1). Rubanda District became operational on 1 July 2016 curved out of the neighboring Kabale District.

According to UBOS data, Rubanda District population for 2019 is projected at 205,000 people and is expected to reach 206,600 by 2020 (UBOS, 2017). The District is largely composed of youth with over $54 \%$ below 17 years of age (UBOS, 2017). Rubanda lies at an approximate altitude of $1200 \mathrm{~m}-3000 \mathrm{~m}$ above sea level (Kabale District Local Government (KDLG), 2011). The district has an elevated altitude between $1200 \mathrm{~m}$ to $3000 \mathrm{~m}$ above sea level, with volcanic mountains and hills, separated by $\mathrm{V}$-shaped valleys. Rubanda has a montane climate with two rainfall seasons with the first from March to May and the second from September to November and two dry periods of June to August and December to February (Mugagga et al., 2019). It receives heavy rains with a mean annual rainfall of $1480 \mathrm{~mm}$ per annum (KDLG, 2011).

The soils are generally volcanic and fertile, whereas other parts have less fertile ferrallisols and andosols (Figure 1). Soils on the hills are generally ferralitic and are in advanced stage of weathering with little or no mineral resources to draw on (Bagoora, 2010). The soils include; clay-loam, peat clay and alluvium peat. The topography is composed of flat-topped hills alternated by U-shaped valleys. The valleys lie at altitudes as low as $1200 \mathrm{~m}$ and the hilltops rise over $2000 \mathrm{~m}$. The District is underlain by the oldest rock system, the Precambrian age Karagwe-Ankolean system which consists of swamp deposits and alluvium (Pleistocene), shale, phyllites and quartzite (KDLG, 2011).

Rubanda District was purposively selected for the study because it has the highest production level of potato in Western Uganda with 45, 578 metric tons produced annually (UBOS, 2010). Two sub-counties (Muko and Bubaare) were purposively selected because of their unique characteristics that is, highly populated, 


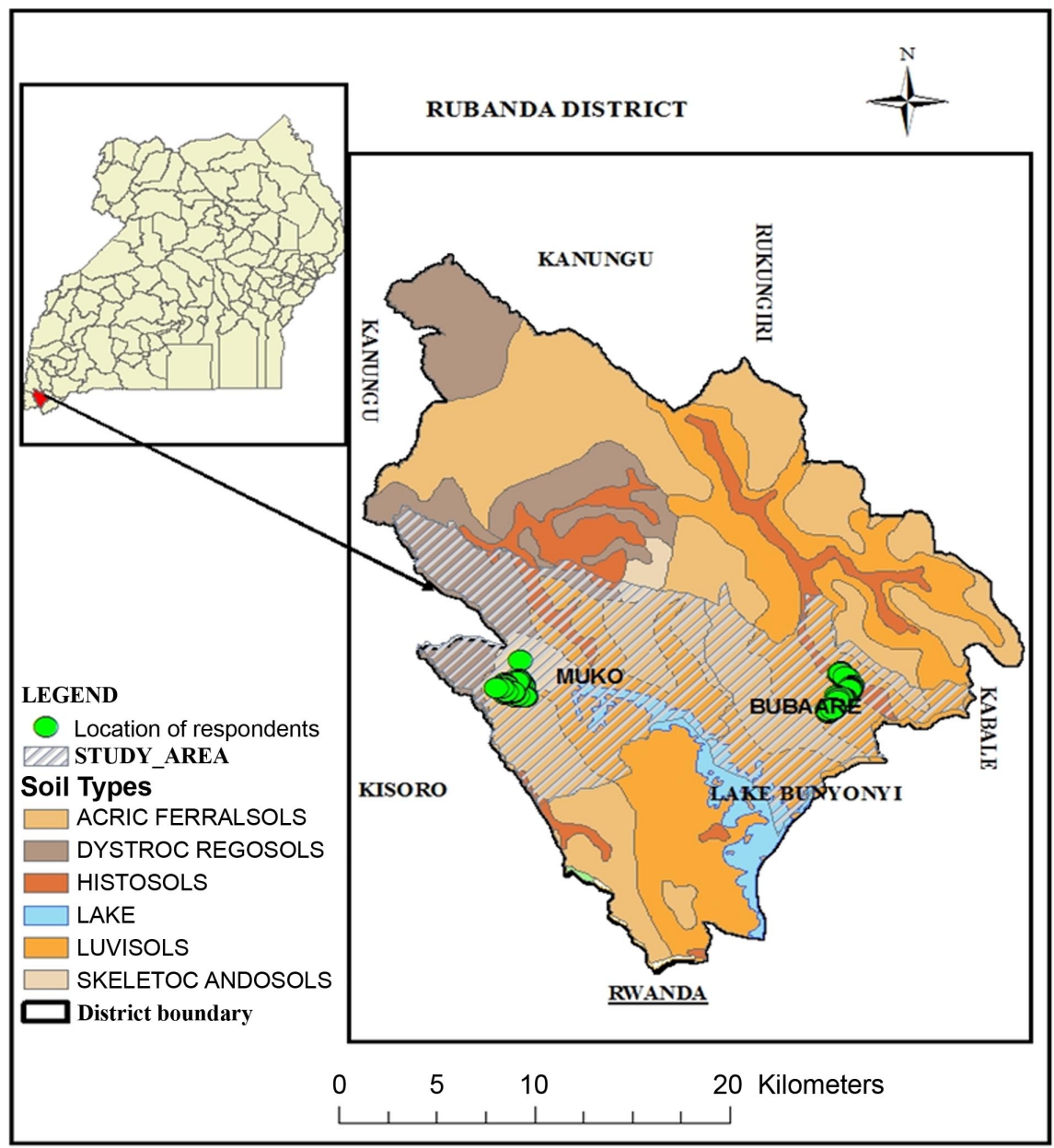

Figure 1. Map showing the location of the study area.

highest producers of Irish potatoes, a home to the agricultural research institutes and they are located at different sub agro-ecological zones based on altitude, temperatures, rainfall, soil types, and vegetation cover as approved by the District council (KDLG, 2015). Muko is located in high altitude (1900-2700), cold temperatures, high rainfall $(1780 \mathrm{~mm})$, fertile volcanic soils and steep hills with V-shaped valleys whereas Bubaare is at zone 3 with medium altitude (1800-1900), high rainfall, cool temperatures, loam peat soils and U-shaped valleys (KDLG, 2011; KDLG, 2015).

\section{Sampling Procedure}

Systematic random sampling was used to select the respondents because the study was interested in only smallholder farmers, therefore those involved in large-scale farming were eliminated. This gave all the target respondents equal chances of selection hence precluding selection bias and also ensured that only smallholders were selected to increase the validity of the results. Smallholders in this study were small farms relying on family labour for most of the production process, subsistence oriented and supporting a single family. 
Methodological triangulation was used for data collection and collation to ensure validity and reliability of the findings (Bryman, 2008).

Data was collected using a structured questionnaire administered to a total of 197 respondents. The sample size was obtained using a formula by Yamane (1967).

$$
n=\frac{N}{1+N\left(e^{2}\right)} .
$$

where $n=$ sample size, $N=$ total number of households involved in subsistence farming, $e=$ margin of error set at $10 \%$.

This was triangulated with Key Informant Interviews (KII) and Focus Group Discussions (FGDs). Depth interviews involving six key informants from the district local government, civil society organizations and an agricultural research organization were conducted. Also, two FGDS were conducted with the locals who were deemed to have the required information.

To ensure validity of the study and reliability of questions in the data collection instruments, a pilot study was conducted in Bubaare sub-county before embarking on a field survey.

\section{Data Analysis}

All the returned questionnaires were edited and cleaned to ensure that the required information had been captured to ease analysis. The data was entered in a Statistical Package for Social Scientists (SPSS) Version 23 for data analysis. Exploratory data analysis was carried out for the survey data to check for outliers, normality and symmetry.

The Likert scale used to determine perception towards the effectiveness of climate variability adaptation measures among different farmers was summarized using descriptive statistics. A four (4) point scale from not effective to effective was used; Whereby, one represented not effective, two as least effective, three as moderately effective and four as effective. Results from the Likert scale were triangulated with the Cobb-Douglas production function.

The Cobb-Douglas production function was used to measure the effectiveness of adaptation measures adopted by farmers. A production function is a mathematical description of the various production activities and it is used to depict the relationship between an output to input (Gorgess \& Naby, 2012). The production function is used in conjunction with the marginal productivity theory to explain how much of output can be produced by adding one unit of input while holding all other factors constant.

Bhanumurthy (2002) gives the mathematical formula of the Cobb-Douglas production function as:

$$
\begin{aligned}
Q=A_{i t} K_{i t}^{\beta k} L_{i t}^{\beta l} & \text { represented as; } \\
& Q=f(C P, L D, L B)=A C P L D L B
\end{aligned}
$$

where $Q$ is the output produced, $C P, L D, L B$ are capital, land and labour inputs 
used in production and $A$ is a positive constant and $a, b$ and $c$ are coefficients.

The Cobb-Douglas production function is used to analyse production processes because it can handle multiple inputs in its generalised form. Various multiple regression estimation problems such as serial correlation, hetroscidacity and multi-collinearity can be addressed well and adequately using the function (Bhanumurthy, 2002).

The Cobb-Douglas production function has proved to be useful in many applications because it is linear in logarithm:

$$
\ln (Q)=\ln (A)+\ln (C P)+b \ln (L D)+c \ln (L B)
$$

The coefficients $\mathrm{a}, \mathrm{b}$ and $\mathrm{c}$ are the elasticities of output with respect to capital, land and labour respectively. In this study, the variables are; land, labour, capital, fertilizer use, time of planting, irrigation, mulching, migration, rainwater harvesting, off-farm activities and borrowing.

$$
Q=A X_{1}^{b 1} X_{2}^{b 2} \cdots X_{11}^{b 11}+e
$$

$Q=$ output of Irish potato in $\mathrm{Kg}$

$A$ is a constant

$b_{1} \ldots b_{11}$ are the coefficients that were estimated by converting the variables into their natural logarithms.

$$
\ln Q=\ln a+b_{1} \ln X_{1}+b_{2} \ln X_{2} \cdots B_{11} \ln X_{11}+e
$$

where, $b_{1} \ldots B_{12}$ are coefficients

$X_{1}=$ Area of land used for Irish growing in acres

$X_{2}=$ mean household size required from planting to harvesting

$X_{3}=$ total amount of money for Irish growing in shillings

$X_{4}=$ fertilizer use (cost of fertilizer used in UGX)

$X_{5}=$ time of planting (month of the year)

$X_{6}=$ irrigation $(1=$ yes, $0=$ no $)$

$X_{7}=$ mulching $(1=$ yes, $0=$ no $)$

$X_{8}=$ water harvesting $(1=$ yes, $0=$ no $)$

$X_{9}=$ migration $(1=$ yes, $0=$ no $)$

$X_{10}=$ off-farm activities $(1=$ yes, $0=$ no $)$

$X_{11}=$ Borrowing $(1=$ yes, $0=$ no $)$

Regarding qualitative data obtained from FGDs and Key informant interviews, the information was organized using color-coding technique into themes and organized into coherent categories based on the theoretical, conceptual framework and objectives of the study. Themes were generated from the structured data to determine patterns and connections in the data and classified for analysis. Narratives (raw data) were also used to emphasize the voices of the respondents.

\section{Results and Discussion}

\subsection{Socio-Economic Characteristics of the Respondents}

Below is a presentation of the key characteristics of the respondents involved in 
study:

Majority of the household heads (79.7\%) were of the male gender with only $20.3 \%$ female headed households. A large proportion of the respondents (78.2\%) were married (Table 1). Regarding the level of education, most of the respondents

Table 1. Socioeconomic characteristic of the respondents.

\begin{tabular}{|c|c|c|}
\hline Characteristic/Variable & Frequency & Percent \\
\hline \multicolumn{3}{|l|}{ Sex of the household head } \\
\hline Male & 157 & 79.7 \\
\hline Female & 40 & 20.3 \\
\hline \multicolumn{3}{|l|}{ Marital Status } \\
\hline Single & 13 & 6.6 \\
\hline Married & 154 & 78.2 \\
\hline Widowed & 30 & 15.2 \\
\hline \multicolumn{3}{|l|}{ Level of education } \\
\hline Primary & 132 & 67.0 \\
\hline Secondary & 40 & 20.3 \\
\hline University/tertiary & 5 & 2.5 \\
\hline None & 20 & 10.2 \\
\hline \multicolumn{3}{|l|}{ Household size } \\
\hline$<5$ & 118 & 59.9 \\
\hline $5-10$ & 76 & 38.6 \\
\hline$>10$ & 3 & 1.5 \\
\hline \multicolumn{3}{|l|}{ Years spent in the area } \\
\hline $0-5$ & 14 & 7.1 \\
\hline $6-11$ & 7 & 3.6 \\
\hline $12-17$ & 15 & 7.6 \\
\hline 18 above & 161 & 81.7 \\
\hline \multicolumn{3}{|l|}{ Land owned(acres) } \\
\hline$<1$ & 121 & 61.4 \\
\hline $2-5$ & 56 & 28.4 \\
\hline $5-8$ & 14 & 7.1 \\
\hline $9-12$ & 6 & 3.0 \\
\hline \multicolumn{3}{|l|}{ Tenure type } \\
\hline Lease & 2 & 1.0 \\
\hline Customary & 184 & 93.4 \\
\hline Rented & 11 & 5.6 \\
\hline \multicolumn{3}{|l|}{ Off-farm employment } \\
\hline Yes & 80 & 43 \\
\hline No & 106 & 57 \\
\hline
\end{tabular}

$N=197$. 
were semi-illiterates having attained primary level education. Only $20.3 \%$ had secondary education while about just $2 \%$ had tertiary or university education. Further analysis reveals that a large proportion of those with no education was higher in females compared to males. Most of the households interviewed had less than 5 members (59.9\%) with only $1.5 \%$ having 10 and above members. The results also revealed that majority of the respondents (81.7\%) interviewed were those who had stayed in the area for close to two decades (18 above). In terms of land ownership, a majority of the respondents owned less than one acre of land which depicts shortage of land for agricultural expansion and also a recipe for land degradation and encroachment of marginal lands. In Rubanda District, an absolute majority (93.4\%) privately and customarily own land through inheritance from the parents. About $43 \%$ of the households were involved in off-farm activities to augment the farm output.

\subsection{Perception of Respondents on Effectiveness of Adaptation Measure}

Farmers were given to rank on a scale of 1 - 4 the effectiveness of adaptation measures they applied. The results are represented in the (Table 2).

Early planting was rated as the most effective adaptation measure adopted by Irish potato smallholder farmers in Rubanda District (73.6\%) in (Table 2). This was selected to be the most effective because early planting is necessary to take advantage of the early rains. This is based on the fact that the rainfall seasons have become variable and unpredictable in the area. Farmers can no longer predict the onset and cessation of rainfall thus they must adjust their planting time accordingly to fit into the new situation. In fact, early planting was reported by Hijmans (2003) as a key factor in increasing potato yields. He argued that adapting the planting time by planting early will be key for potato farmers. Similarly, Franke et al. (2015) reported it as a key adaptation measure among the South African farmers with the potential to increase production of potato farmers. The

Table 2. Effectiveness of the adaptation measures as perceived by smallholder Irish potato farmers in Rubanda District.

\begin{tabular}{ccccc}
\hline Adaptation measure & $\begin{array}{c}\text { Not } \\
\text { effective \% }\end{array}$ & $\begin{array}{c}\text { Least } \\
\text { effective \% }\end{array}$ & $\begin{array}{c}\text { Moderately } \\
\text { effective \% }\end{array}$ & Effective \% \\
\hline Migration & 91.2 & 3.3 & 2.2 & 3.3. \\
Borrowing & 19.8 & 24.5 & 34.9 & 20.7 \\
Irrigation & 62.3 & 13 & 10.1 & 14.5 \\
Planting fast maturing varieties & 5.2 & 7 & 27.8 & 70 \\
Planting drought tolerant varieties & 23.3 & 21.4 & 24.3 & 31.1 \\
Early planting & 4.7 & 4.1 & 17.6 & 73.6 \\
Application of fertilizers & 5.8 & 12.1 & 17.8 & 64.5 \\
Terracing & 5.3 & 5.3 & 19.5 & 69.9 \\
\hline
\end{tabular}

NB: Total respondents, $N=197$. 
other measures rated to be effective were planting fast maturing varieties $(70 \%)$, terracing (69.9\%) and application of fertilizers with $64.5 \%$.

Migration was found to be ineffective with an overwhelming majority (91.2\%) of respondents rating it to be not effective. Although migration has been reported by previous studies among the adaptation measures (Muhumuza et al., 2010; Zizinga et al., 2015) in Uganda, they do not measure up to the level of being successful. Brooks et al. (2011) did advance that successful adaptation measures should be sustainable, acceptable and coherent among others. Migration is categorized in the NAPA report as having negative benefits. For example, migration is deemed to cause family disintegration and conflicts (NAPA, 2007).

From the focus group discussions and key informant interviews, findings reveal that smallholder Irish potato farmers are cultivating in wetlands during off-season especially during June-September to take advantage of the residual moisture. This was confirmed by the Principal Technician at Kachwekano Zonal Agricultural Research Institute.

Some farmers argued that due to land shortage and fragmentation, planting in the wetlands and swamps is one of their adaptive measure. Although off-season Irish potatoes are reportedly less prone to late blight (Kaguongo et al., 2008), cultivation in wetlands has negative implications on the ecosystem services such as water purification, erosion control and flood buffering. Cultivating in wetlands is not sustainable as it also compromises water quality thus further exposing the smallholder farmers to other risks. The Uganda National Land Policy (2013) and the NAPA Report, cite cultivation on the marginal lands such as wetlands as one of the unsustainable measures that farmers have used (Ministry of Lands Housing and Urban Development., 2013; NAPA, 2007). This is a maladaptation measure that has environmental repercussions.

Discussions with the farmers revealed that the quality of agricultural chemicals is wanting. The farmers argued that although they use chemicals to deal with the pests and diseases that attack the crop, they are not effective. They attribute this to malicious drug stockers who sell the unsuspecting farmers with fake or adulterated chemicals. Their assertion is supported by Mbowa \& Mwesigye (2016) and UNSPPA (2018) who revealed the use of adulterated agro-inputs such as pesticides and fungicides in the market to be one of the challenges that Irish potato farmers face. Besides, the ineffectiveness of pesticides could be explained by resistance that some of the diseases have developed towards pesticides. For example, Kaguongo et al. (2008) observed that late blight pathogen (phytophthora infestans) had developed vertical resistance to fungicides in both Uganda and Kenya.

The effectiveness of the measures was analyzed using the Cobb-Douglas production function. A multiple linear regression was conducted to determine the best linear combination of capital, labor, land, irrigation, fertilizers, time of planting, mulching, irrigation, rain water harvesting, borrowing and off-farm employment for predicting production output of Irish potatoes. Table 3 shows a summary of regression coefficients estimated by converting the variables into 
Table 3. Multiple linear regression analysis for cobb-douglas production Function with dependent variable being output of Irish potato $(\mathrm{kg})$.

\begin{tabular}{cccccc}
\hline \multirow{2}{*}{ Independent variables } & \multicolumn{2}{c}{$\begin{array}{c}\text { Unstandardized } \\
\text { Coefficients }\end{array}$} & $\begin{array}{c}\text { Standardized } \\
\text { Coefficients }\end{array}$ & t-Value & \multirow{2}{*}{$\boldsymbol{P}$-Value } \\
\cline { 2 - 3 } & B & Std. Error & Beta & & \\
\hline (Constant) & 2.462 & 0.803 & & $3.064^{* *}$ & 0.003 \\
Capital & -0.018 & 0.020 & -0.053 & -0.915 & 0.362 \\
Labour & 0.155 & 0.465 & 0.017 & 0.334 & 0.739 \\
Land under potato & 0.437 & 0.382 & 0.062 & 1.144 & 0.254 \\
Fertilizers & 0.483 & 0.033 & 0.768 & $14.790^{* * *}$ & 0.000 \\
Time of planting & -0.348 & 0.123 & -0.146 & $-2.836^{* *}$ & 0.005 \\
Mulching & 0.094 & 0.305 & 0.016 & 0.307 & 0.759 \\
Irrigation & 0.514 & 0.422 & 0.063 & 1.218 & 0.225 \\
Rainwater harvesting & 0.020 & 0.222 & 0.005 & 0.089 & 0.930 \\
Migration & 0.310 & 0.554 & 0.029 & 0.560 & 0.576 \\
Off-farm activities & 0.107 & 0.219 & 0.025 & 0.487 & 0.627 \\
Borrowing & 0.027 & 0.239 & 0.006 & 0.113 & 0.910 \\
\hline
\end{tabular}

Notes; $\mathrm{R}^{2}=0.603, \mathrm{~F}(11,164)=22.607, P<0.001 ;{ }^{* *},{ }^{* *},=$ Significant at $P<0.001$, and $P<0.01$, respectively.

their natural logarithms. A combination of explanatory variables significantly predicted production, $\mathrm{F}(11,164)=22.607, P<0.001$ with two variables significantly contributing to the prediction. The beta weights in Table 2 , suggest that application of fertilizers contributes most to predicting production, although other variables also contribute to this prediction.

The adjusted $\mathrm{R}$ squared was 0.603 . This indicated that $60.3 \%$ of the variance in production was explained by the model. The multiple correlation coefficient, $\mathrm{R}=$ 0.776 indicates that there is a strong correlation between the observed production levels and those predicted by the regression model.

The sum of all the regression coefficient values of the explanatory variables was 1.781 which is greater than one. This indicates that the Cobb-Douglas function exhibits increasing returns to scale (IRTS) and means that output increases more than the proportional change in all the inputs in the model. It suggests that if relevant inputs are increased by a given percentage, the output of Irish potatoes will increase by a greater percentage.

From Table 2, it is evident that some of the variables were found to be significantly predicting production. For instance, increased application of fertilizer and time of planting were significantly associated with productivity. However, although the coefficients for the rest of the variables were as predicted, capital was found to be negatively associated with production contrary to the literature and the theoretical assumptions of the Cobb-Douglas production model. Fellipe \& Adams (2005) in their retrospective view on the Cobb-Douglas production 
function re-estimated the function by including an exponential time trend $(T)$ as suggested by Samuelson (1979), that is, $Q_{t}=B e^{\lambda T}\left(L_{t}\right)^{\alpha}\left(K_{t}\right)^{\beta}$. The results were somewhat surprising in that the coefficient of the index of capital was negative and insignificant. They continued however, to note that the result of a negative capital coefficient is not a new phenomenon when estimating the Cobb-Douglas production functions. The negative coefficient of the index of capital was also a standard finding in (Lucas, 1970; Romer, 1987; Klette and Griliches, 1996; Griliches and Mairesse, 1998).

A one-unit positive change in application of fertilizers, all other predictors held constant, will increase the production of Irish potato by $48.3 \mathrm{~kg}$. The application of fertilizers, both organic and inorganic, has the potential to increase the productivity of Irish potato in the region. This is in tandem with the observations by Kikoyo \& Nobert (2015) that optimal application of fertilizers increased maize yields in Uganda by more than $50 \%$ for dry years and $60 \%$ for wet years. Besides, McCambell (2015) posited that fertilizers help to regain the lost soil nutrients and had the potential to raise smallholder farmer productivity in Uganda.

Regarding the time of planting, the result suggests that a one-month increase in the planting time would decrease the productivity of the potato by $34.8 \mathrm{~kg}$. This implies that early planting will be important in circumventing the climate variability vagaries. It also means that late planting decreases productivity of Irish potatoes. The results agree with Hijmans (2003) who observed that potential potato yield losses decreases were higher without adapting the planting time than when the adaptation of planting time was involved. Karanja (2013) also reported that timely planting was the most important adaptation measure that farmers in Nyandarua county in Kenya had used.

\section{Conclusion and Policy Implications}

Literature reveals that climate variability will adversely affect the agricultural sector and yet the sector remains the main source of livelihood among the smallholder farmers in Uganda. This makes adaptation to climate variability imperative as a means to reduce sensitivity and exposure to the associated impacts.

Adaptation to climate variability impacts therefore, is necessary to assess the degree to which the measures can moderate or bring down negative impacts of climate change and variability, or actualize positive effects presented by climate variability.

This study aimed to appraise smallholder Irish potato farmers' perceptions about the effectiveness of climate variability adaptation measures and implication on Irish potato productivity in Rubanda District

The appraisal has revealed that the most effective adaptation measures are: use of fertilizers, early planting, planting adaptive potato varieties contour ploughing and terracing. Based on the estimates of the Cobb-Douglas production function, the paper concludes that; early planting and application fertilizers have the ca- 
pacity to increase the productivity of the potato in Rubanda. The application of fertilizers has the potential to restore lost soil fertility that has been caused by severe erosion in the area. However, this will be plausible on steep slopes only with proper management of erosion such the use of terraces, contour ploughing and agroforestry trees.

However, given the unsustainability of some of the measures such as off-season planting in wetlands and migration, the study concludes that measures that are cost effective, efficient and coherent should be promoted to offset the impacts of climate variability in the District. It is also imperative that the Ministry of water and Environment together with the National Environment Management Authority ensure full implementation and enforcement of wetland protection laws in Uganda.

\section{Acknowledgements}

We acknowledge the Makerere-Sida Capacity Building Programme 2015-2020 under the Partnership for Building Resilient Ecosystems and Livelihoods to Climate Change and Disaster Risks (BREAD) project that funded the study. We also thank the Almighty for his providence and comfort which enabled the completion of this paper.

\section{Conflicts of Interest}

The authors declare no conflicts of interest regarding the publication of this paper.

\section{References}

Adger, W. N., Arnell, N. W., \& Tompkins, E. L. (2005). Successful Adaptation to Climate Change across Scales. Global Environmental Change, 15, 77-86. https://doi.org/10.1016/j.gloenvcha.2004.12.005

Ampaire, E. L., Jassogne, L., Providence, H., Acosta, M., Twyman, J., Winowiecki, L., \& Van Asten, P. (2017). Institutional Challenges to Climate Change Adaptation: A Case Study on Policy Action Gaps in Uganda. Environmental Science and Policy, 75, 81-90. https://doi.org/10.1016/j.envsci.2017.05.013

Asefa, S. (2011). Munich Personal RePEc Archive Analysis of Technical Efficiency of Crop Producing Smallholder Farmers in (No. 40461). Personal Munich Repec Archive. https://mpra.ub.uni-muenchen.de/40461

Bagoora, F. K. (2010). Challenges of Climate Change in Mounatin Ecosystems in Africa Kampala. In United Nations Climate Change Conference COP16 and CMP6, Cancun, Mexico (p. 29). Kampala: National Environment Management Authority (NEMA).

Bhanumurthy, K. V. (2002). Arguing a Case for the Cobb-Douglas Production Function. Review of Commerce Studies, 75-91.

Brooks, N., Anderson, S., Ayers, J., Burton, I., \& Tellam, I. (2011). Tracking Adaptation and Measuring Development (No. 1). http://pubs.iied.org/pdfs/10031IIED.pdf

Bryman, A. (2008). Social Research Methods (3rd ed.). London: Oxford University Press.

Byamukama, W., Bello, N., \& Omoniyi, T. (2018). Farmers' Perception of the Impacts of Climate Variability and Change on Food Security in Rubanda District, South Western 
Uganda. Journal of Environment and Health Science, 4, 64-73.

Byishimo, P. (2017). Assessment of Climate Change Impacts on Crop Yields and Farmers' Adaptation Measures: A Case of Rwanda. Harare: University of Zimbabwe.

CDKN (2015). Economic Assessment of Impacts of Climate Change in Uganda. Kampala: Climate and Development Knowledge Network. http://www.CDKN.org

Dharmasiri, L. M. (2009). Measuring Agricultural Productivity Using the Average Productivity Index.

Fellipe, J., \& Adams, G. (2005). "A Theory of Production" The Estimation of the CobbDouglas Function: A Retrospective View. Eastern Economic Journal, 31, 427-446.

Franke, A. C., Haverkot, A. J., \& Steyn, J. M. (2015). Climate Change and Potato Production in Contrasting South African Agro-Ecosystems 2. Assessing Risks and Opportunities of Adaptation Strategies. Potato Research, 56, 51-66.

Gorgess, H. M., \& Naby Abdul, A. I. (2012). Using Restricted Least Squares Method to Estimate and Analyse the Cobb-Douglas Production Function with Application. Ibn AL-Haitham Journal of Pure and Applied Science, 25, 359-368.

Hepworth, N., \& Goulden, M. (2008). Climate Change in Uganda: Understanding the Implications and Appraising the Response. Edinburgh: LTS International.

Hijmans, R. J. (2003). The Effect of Climate Change on Global Potato Production. American Journal of Potato Research, 80, 271-280. https://doi.org/10.1007/BF02855363

Hisali, E., Birungi, P., \& Buyinza, F. (2011). Adaptation to Climate Change in Uganda: Evidence from Micro Level Data. Environmental Change, 21, 1245-1261.

https://doi.org/10.1016/j.gloenvcha.2011.07.005

Kabale District Local Government (KDLG) (2011). Kabale District Local Government Five Year Development Plan, 2011/201-2015/2016(Vol. 1). Kabale.

Kabale District Local Government (KDLG) (2015). Kabale District Five Year Development Plan, 2015/2016-2019/2020. Kabale.

Kaguongo, W., Gildemacher, P., Demo, P., Wagoire, W., Kinyae, P., Andrade, J., Fuglie, K. et al. (2008). Farmer Practices and Adoption of Improved Poatao Varieties in Kenya and Uganda (No. 5). Social Sciences Working Paper 2008-5, Lima.

Karanja, A. M., Shasanya, C., \& Makokha, G. (2014). Analysis of Rainfall Variability on Potato Production in Kenya: A Case of Oljoro-Orok Division. Asian Journal of Applied Sciences, 2, 447-456.

Kikoyo, D. A., \& Nobert, J. (2015). Assessment of Impact of Climate Change and Adaptation Strategies on Maize Production in Uganda. Physics and Chemistry of the Earth, 93, 37-45. https://doi.org/10.1016/j.pce.2015.09.005

Kotulič, R., \& Pavelková, J. (2014). The Application of the Cobb-Douglas Production Function in Analyzing the Effectiveness of Productive Resources in Agricultural Enterprises of Primary Production. Journal of Central European Agriculture, 15, 284-301. https://doi.org/10.5513/JCEA01/15.3.1489

MAAIF (2010). Agriculture Sector Development Strategy and Investment Plan, 2010/11$2014 / 15$.

Mbowa, S., \& Mwesigye, F. (2016). Investment Opportunities and Challenges in the Irish Potato Value Chain in Uganda. Kampala: EPRC.

McCambell, I. (2015). Fertilizer Adoption Challenges among Potato Farmers in Uganda: Analysis of a Complex Problem Using an Innovation Systems. Wageningen: Wageningen Univeristy.

Ministry of Lands Housing and Urban Development (2013). The Uganda National Land 
Policy. Kampala.

Mugagga, F., Elepu, J., Nimusiima, A., \& Bamutaze, Y. (2019). Institutional Determinants to Climate Variability Adaptation by Smallholder Irish Potato Farmers in Rubanda District, South Western Uganda. American Jouranal of Climate Change, 8, 77-93. https://doi.org/10.4236/ajcc.2019.81005

Muhumuza, M., Muzinduki, P., \& Hyeroba, G. (2010). Small Holder Farmers' Knowledge and Adaptation to Climate Change in the Rwenzori Region. Rwenzori Journal, 1, 117133.

NAPA (2007). Ugnada National Adaptation Programmes of Action. Kampala.

Prasad, T., \& Wagle, S. (2016). Spatial Analysis of Cob-Douglas Production Function in Agriculture Sector of Nepal: An Empirical Analysis. Journal of Advanced Academic Research, 3, 101-114. https://doi.org/10.3126/jaar.v3i2.16759

Regmi, B. R., Sthrestha, K., Sapkata, R., \& Pathak, K. (2018). What Constitutes Successful Adaptation Measures? Reflections from the National and Local Context of Nepal (No. 17). Kathmandu: HI-AWARE.

Twagiramaria, F., \& Tolo, C. U. (2016). Climate Variability and Soil Nutrients Status along Altitudinal Gradient in Kigezi Highlands, Southwestern Uganda. Natural Resources, 7, 1-22. https://doi.org/10.4236/nr.2016.71001

UBOS (2010). Uganda Census of Agriculture, 2008/2009. Kampala.

UBOS (2016). The National Population and Housing Cencus 2014. Kampala.

UBOS (2017). Uganda Bureau of Statistics 2017 Statistical Abstract. Kampala.

Uganda National Seed Potato Producers Association (UNSPPA) (2018). Potato Week (7th Ed.). Amhem.

Yamane, T. (1967). Statistics: An Introductory Analysis (2nd ed.). New York: Harper and Row.

Zizinga, A., Tenywa, M. M., Majaliwa, J. G. M., Mugarura, M., \& Ababo, P. (2015). Potential Climate Change Adaptation and Coping Practices for Agricultural Productivity in the Mountain Areas of South Western Uganda. Journal of Scientific Research and Reports, 7, 23-41. https://doi.org/10.9734/JSRR/2015/16351 